\title{
Communication/Comunicação
}

\section{New report on the bionomics of Coquillettidia venezuelensis in temporary breeding sites (Diptera: Culicidae)}

\author{
Novo relato sobre a bionomia de Coquillettidia venezuelensis em criadouros temporários \\ (Diptera: Culicidae)
}

\section{Jeronimo Alencar ${ }^{1}$, Juliana Barreto Pacheco ${ }^{1}$, Fabiana Fagundes Correa ${ }^{1}$, Júlia dos Santos Silva ${ }^{1}$ and Anthony Érico Guimarães ${ }^{1}$}

\begin{abstract}
Introduction: Findings of immature forms of Coquillettidia venezuelensis in temporary breeding sites, without the presence of aquatic plants or other submerged plant tissue are reported. Methods: A systematic scooping technique to collect specimens was used at the breeding site. Results: Immature forms of Coquillettidia venezuelensis, Anopheles rangeli, An. evansae and Culex sp. were collected from areas of the hydroelectric power station of São Salvador, State of Goiás. Conclusions: This is a novel finding relating to the bioecology of $C q$. venezuelensis, a species of medical interest that has been found naturally infected with arboviruses, including Oropouche and West Nile virus.
\end{abstract}

Keywords: Culicidae. Coquillettidia venezuelensis. Immature forms. Transitory breeding sites.

\section{RESUMO}

Introdução: Relata-se o encontro de formas imaturas de Coquillettidia venezuelensis em criadouros temporários, sem presença de plantas aquáticas ou outros tecidos vegetais submersos. Métodos: Realizaram-se coletas com a técnica de conchadas sistemáticas na margem do criadouro. Resultados: Foram coletados imaturos de Coquillettidia venezuelensis, Anopheles rangeli, An. evansae e Culex sp., em áreas da Usina Hidrelétrica de São Salvador, Estado de Goiás. Conclusões: Trata-se de observação inédita sobre a bioecologia de $C q$. venezuelensis, espécie de interesse médico, que tem sido encontrada naturalmente infectada com arbovírus, inclusive Oropouche e West Nile.

Palavras-chaves: Culicidae. Coquillettidia venezuelensis. Formas imaturas. Criadouros transitórios.

The breeding sites for species of Coquillettidia consist of medium to large water accumulations, such as lakes, stagnant pools, swamps and backwaters of rivers. The eggs are deposited in groups under the leaves of aquatic plants, particularly grassy plants ${ }^{1}$, and the larvae attach themselves to the roots and take oxygen directly from the aeriferous parenchyma. These plants have the capacity to increase their biomass rapidly, through sexual or asexual reproduction, thus constituting an excellent substrate for many animals ${ }^{2}$.

Coquillettidia are hematophagous, aggressive and voracious insects, with a preference for nocturnal activity. The epidemiological significance of the group comes from the fact that they have

1. Laboratório Diptera, Instituto Oswaldo Cruz, Fundação Oswaldo Cruz, Rio de Janeiro, RJ.

Address to: Dr. Jeronimo Alencar. Lab. Diptera/IOC/FIOCRUZ. Av. Brasil 4365, Manguinhos, 21040-360 Rio de Janeiro, RJ, Brasil.

Tel: 5521 2562-1450

e-mail: jalencar@ioc.fiocruz.br

Received in 04/05/2010

Accepted in 10/01/2011 been found naturally infected by dangerous arboviruses, such as Oropouche $\mathrm{e}^{1,3}$. In the specific case of Coquillettidia venezuelensis, specimens infected with the virus that causes West Nile fever were recently isolated in studies that are being conducted at Laguna de los Patos, municipality of Cumana, State of Sucre, Venezuela (personal communication from Glenda Velásquez, MSc, Health Investigation Division, INSALUD, Ministry of Health, Venezuela).

The present study aimed to characterize findings of immature forms of culicids by rearing them in transitory breeding sites.

It was conducted as part of the process of vector monitoring in areas under direct influence from the reservoir of the hydroelectric power station of São Salvador, municipality of Minaçu, State of Goiás, at the coordinates $13^{\circ} 18^{\prime} 12^{\prime \prime} \mathrm{S}$ and $48^{\circ} 09^{\prime} 18^{\prime \prime \prime} \mathrm{W}$, and at an altitude of $307 \mathrm{~m}$. The collection locality presented vegetation of riverbank forest type that was reasonably well preserved.

In June and April 2010, immature forms were systematically collected along the edges of the breeding sites with the aid of entomological scoops (BioQuip $\left.{ }^{\circledR}\right)$. The water was poured into polyethylene trays and any larvae and insects that were present were removed with the aid of a thin brush. Following this, the larvae and pupae were pipetted to pack them into $250 \mathrm{ml}$ plastic bags (Whirl-Pak Bags) for transportation. In the laboratory, the larvae were screened for transfer to small individual pots, where they were maintained in water taken from the breeding site that was topped up periodically with distilled water. The larvae were maintained alive in an attempt to continue with the life cycle. The pupae were transferred to small tubs, where they remained until reaching the adult stage.

The culicids were identified by direct observation of morphological characteristics, which were evident under an optical microscope, based on dichotomous keys ${ }^{4-6}$. A toal of 319 specimens of Culicidae were collected, consisting of Cq. venezuelensis (239), Anopheles rangeli (21), An. evansae (3) and Culex sp. (49). It should be noted that the locality where the specimens of $C q$. venezuelensis were collected was water accumulation produced by rain. No floating or partially immersed macrovegetation was present or formed part of the breeding site community and the closest river (the Traíra river) was 10 meters below the level of the sampling point and at a distance of $100 \mathrm{~m}$ away, with a medium speed of current flow. Thus, we rejected the hypothesis that these immature forms might have been displaced, arriving at the breeding site in question because of the river overflowing due to excess rainwater (Figure 1). 


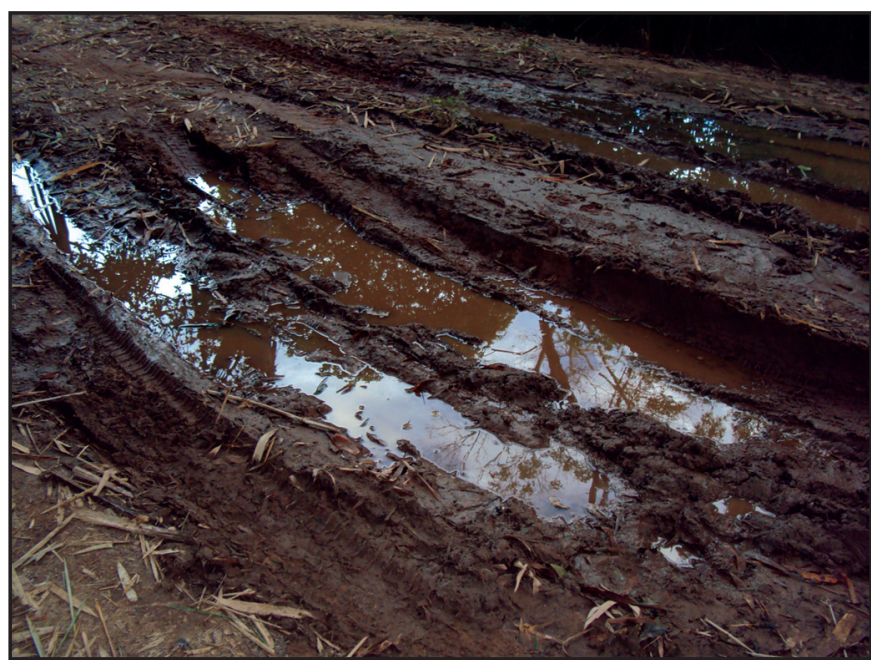

FIGURE 1 - Appearance of the temporary breeding site in which the immature forms of Coquillettidia venezuelensis were found.

Despite the total lack of aquatic vegetation, observation confirmed that the immature forms must have been at the site for at least $238 \mathrm{~h}$ prior to collection. At the time of sampling, the water at this site was cloudy, the temperature was $24^{\circ} \mathrm{C}$ and the $\mathrm{pH}$ was 7.0.

In studies ${ }^{7}$ conducted to determine the diversity of mosquito fauna in three different wetlands in Maryland, United States, which also presented breeding sites in temporary pool areas, a total of 14 species were collected. Ten of the species were collected at both the larval and adult development stages, while no immature forms were collected for three species: Aedes albopictus (Skuse), Coquillettidia perturbans (Walker) and Culex restuans Theobald.

Coquillettidia breeding sites consist of medium to large water accumulations and the eggs are deposited in agglutinated clusters underneath leaves in the water. After eclosion, the larvae migrate to open areas and locate the roots of floating plants (Eichornia, Pistia, Salvinia, Typha and grassy plants) or other submerged plant tissue ${ }^{5}$. This pattern was not at all compatible with the present observations. In this case, the lack of aquatic vegetation was not a factor limiting the occurrence of immature forms of $\mathrm{Cq}$. venezuelensis.

Although information regarding the habits of immature forms of $C q$. venezuelensis is scarce, slightly differentiated behavior has also been observed among sedges of the species Fuirena umbellata, in swamps and low-lying areas adjacent to the City of Salvador ${ }^{1}$. In this case, although sedges are not aquatic plants, the immature forms were able to attach themselves to the roots of these plants because they were at the bottom of water accumulations.

In experiments conducted in a laboratory ${ }^{8}$ to reproduce the development cycle of $C q$. richiardii, the larvae were reared on a substrate of soybean bran or algal cultures, in the presence or absence of aquatic plants (Myriophyllum or watercress), which would allow the larvae to become attached. There was almost total mortality on day five (only four out of 56 larvae were still alive), in the medium without plants. In the presence of plants, the duration of the cycle was eight to ten days.

According to observations made while collecting the specimens of $C q$. venezuelensis, they presented completely different behavior regarding their choice of breeding site, showing no association with aquatic plants or other plant material. Thus, in light of this observation, consideration must be given to the fact that the larval community appears to have adapted to breeding sites with no association with aquatic vegetation.
Recent evidence has indicated ${ }^{9}$ that some human activities may contribute towards the expansion of the distribution area of certain species into regions where they had previously not been present. This phenomenon is generally known as biological invasion and it can occur through either deliberate or accidental introduction.

The risks associated with global climatic changes need to be taken into consideration within the context of the globalization of human activities. The impact of such activities is often indirect and mediated by modifications to the environment, such as changes to ecosystems and biogeochemical cycles, which may increase the incidence of infectious diseases ${ }^{10}$. Given that global climatic changes bring new challenges regarding infectious disease control ${ }^{11}$ and that many pathogenic agents and vectors are highly sensitive to climatic factors (temperature and rainfall) that cause health risks, the negative effects resulting from warming of the climate are potentially enormous.

\section{CONFLICT OF INTEREST}

The authors declare that there are no conflicts of interest.

\section{REFERENCES}

1. Forattini OP. Entomologia Médica, Culicini: Culex, Aedes e Psorophora. Vol. 3. São Paulo: Universidade de São Paulo; 1965.

2. Poi De Neiff A. Estructura de la fauna asociada a tres hidrófitos flotantes em ambientes leníticos del nordeste argentino. Comunicaciones Cientificas. Centro de Ecología Aplicada del Litoral; 1977.

3. Hervé JP, Dégallier N, Travassos da Rosa APA, Pinheiro FP, Sá Filho GC. Arboviroses - Aspectos ecológicos. In: Instituto Evandro Chagas-50 anos de contribuição às ciências biológicas e à medicina tropical. Vol. 1. Belém: Fund Serv Saúde Pública; 1986.

4. Lane J. Neotropical Culicidae. Tribe Culicini, Deinocerites, Uranotaenia, Mansonia, Orthopodomyia, Aedomyia, Aedes, Psorophora, Haemagogus, tribe Sabethini, Trichoprosopon, Wyeomyia, Phoniomyia, Limatus and Sabethes. Vol. 2. São Paulo: Universidade de São Paulo; 1953.

5. Consoli RAGB, Oliveira RL. Principais mosquitos de importância sanitária no Brasil. Rio de Janeiro: Editora da Fundação Oswaldo Cruz; 1992.

6. Forattini OP. Culicidologia Médica. Vol. 2. São Paulo: Universidade de São Paulo; 2002.

7. Wagner VE, Efford AC, Williams RL, KirbyJS, Grogan WL. Mosquitoes associated with US Department of Agriculture Managed Wetlands on Maryland's Delmarva Peninsula. J Am Control Assoc 2007; 23:346-350.

8. Colas-Belcour J. L'oeuf et la ponte de Taeniorhynchus (Coquillettidia) richiardii Ficalbi. Bull Soc Pat Exot 1943; 36:101-105.

9. Marcondes CB. Doenças transmitidas e causadas por artrópodes. $1^{\mathrm{a}}$ ed. São Paulo: Atheneu; 2009.

10. Ministério da Saúde. Mudanças climáticas e ambientais e seus efeitos na saúde: cenários e incertezas para o Brasil- Brasil. Brasília: Ministério da Saúde. Organização Pan-Americana da Saúde; 2008. p. 1- 40.

11. Weber CJ. Update on global climate change. Urol Nurs 2010; 30:8184. 